\title{
Room for Manoeuver: Paradox, Program, or Pandora's Box?
}

\section{Boaventura de Sousa Santos}

\section{Epistemological Excursus}

Epicharmus says that "mortals should have only mortal and not immortal thoughts." Using his saying, which I subscribe to, as a criterion to evaluate current social-scientific work, I am led to conclude that we are entering a period of mortal social sciences of which the two articles I am commenting on are good examples, even if both articles have still a certain and subtle Sehnsucht for immortality: Coombe's article, not only by style but also by content; ${ }^{1}$ Trubek's and Esser's article, by its description of the present period of the law and society movement as an autumnal one ${ }^{2}$ (as presumably compared to an hypothetical immortal summer-and I would be tempted to add, with the Brazilian poet Vinicius de Morais, immortal while it lasted).

Positivist social science (of which the instrumental theory is an offspring) has always imposed upon itself strange standards when compared with those guiding common people and their common-sense knowledge. It has made a fundamental distinction between description and evaluation, while common people always muddle them in their verbal and nonverbal practices. It has made a fundamental distinction between the subjectivity of the actors and the behavior of the actors which the actors themselves would never think of making. It has made a fundamental distinction between knowledge and practice, while common-sense knowledge is always

Boaventura de Sousa Santos is professor of sociology, School of Economics, University of Colmbra, Portugal.

1. Rosemary J. Coombe, "Room for Manoeuver: Toward Theory of Practice in Critical Legal Studies," 14 Law \& Soc. Inquiry 69 (1989).

2. David M. Trubek \& John Esser, " 'Critical Empiricism' in American Legal Studies: Paradox, Program, or Pandora's Box?"' 14 Law \& Soc. Inquiry 3 (1989). 
practical knowledge. Because such strange standards have been expounded by important (and equally strange) people, their strangeness easily becomes their superiority vis-à-vis any alternative, even if by far more familiar, standards. Hence their immortal character, most eloquently symbolized in Bachelard's conception of the epistemological rupture. ${ }^{3}$

In the last two decades a renewed interest in epistemology and sociology of science has been questioning the immortality of science. Piaget says that epistemology tends to gain importance in the periods of crisis of science. ${ }^{4}$ If that is the case, it remains to be asked: which type of crisis (degenerative? regenerative?) of which type of science (modern? positivist? structuralist?). In my view, the epistemological struggle against the immortality of science signals a degenerative crisis of modern science and a transition toward a postmodern, mortal science-a science as mortal as the scientists who make it. ${ }^{5}$ This view is anchored in a philosophical tradition whose most salient references are the second: Wittgenstein, ${ }^{6}$ Heidegger, ${ }^{7}$ and Dewey. ${ }^{8}$ Since Heidegger and Dewey seem to have nothing in common, either in philosophical terms (German idealism versus American pragmatism) or in political terms (complicity with nazismus versus a staunch defense of democracy), it may seem odd to put them together. However, they do share the questioning of the foundations of modern, immortal science, which they evaluate in light of its contribution toward the construction of an existential project of life in society. For Heidegger, a pessimist, science and technology promote a dogmatic understanding of being (Sein), reduce existence to its instrumentality (Dasein), thereby preventing its potential for openness and solidarity from being realized (Offenheit, Sorge), which alone grounds an authentic life (Selbstsein). For Dewey, an optimist, science is valued for its relation to the democratic ideal and as long as it keeps such a relation. As a set of practices, science presupposes a certain number of virtues such as imagination and creativity, cooperative spirit, and readiness to submit to the public test which must be actively cultivated in a "creative democracy."

In recent times the critique of the foundations of modern science has

3. Gaston Bachelard, Le Nouvel Esprit Scientifique (Paris: P.U.F., 1971); id, Gaston Bachelard, La Formation de l'Esprit Scientifique (Paris: J. Vrin, 1972).

4. Jean Piaget, ed., Logique et Connaisance Scientifique 7 (Paris: Gallimard, 1967).

5. Boaventura de Sousa Santos, Um Discurso Sobre as Cièncias (Porto: Afrontamento, 1988); id, Introduçāo a Uma Ciència Pós-Modema (Porto: Afrontamento, 1989; forthcoming).

6. Ludwig Wittgenstein, Philosophische Untersuchungen (Frankfurt: Suhrkamp, 1971).

7. Martin Heidigger, Vom Wesen des Grundes (Frankfurt: Klostermann, 1955); id, Was ist Metaphysik? (Frankfurt: Klostermann, 1960); id., Vom Wesen der Wahrheit (Frankfurt: Kostermann, 1961).

8. John Dewey, Essays in Experimental Logic (New York: Dover, 1916); Id, Human Nature and Conduct (New York: Modern Library, 1957); id., Reconstruction in Philosophy (Boston: Beacon Press, 1957); id, The Quest for Certainty (New York: Capricorn Books, 1960); id., Philosophy of Education (Totowa, N.J.: Littlefields, Adams, 1975). 
been extended to the critique of the search for foundations. For instance, Rorty claims that the "epistemology-centered philosophy" is "an episode in the history of European culture" and proposes a pragmatic approach to knowledge, which he calls "epistemological behaviorism." 10 Based on the distinction between normal discourse and abnormal discourse, this approach invites us "to be epistemological" vis-à-vis the normal discourse, and "to be hermeneutical" vis-à-vis the abnormal discourse. Even if epistemology is an episode in European culture I would claim that it is far from having terminated. The paradigmatic crisis of modern science will be a long social process; its revolutionary character owes much more to the Austro-Marxist conception of revolution (long duration) than to the Leninist one (the takeover of the Winter Palace). Paraphrasing Adorno, ${ }^{11}$ one could say that epistemology is false but that it is true in its falsehood. That is, its failure to provide science with an absolute "foundation" legitimizes the continuous search for the precarious truth of a science without foundation.

According to this conception, epistemology should always be pursued as a critique of epistemology. From the point of view of the democratic ideal or of the Selbstsein, modern science is globally an "abnormal discourse" vis-à-vis which we must be hermeneutical. The critical hermeneutics of epistemology, as I call it, is, in our time, the path through which epistemological work can advance. The conception of the transition toward a postmodern science is one possible step along such path.

Such transition can be summarized in my concept of the double epistemological rupture. ${ }^{12}$ Modern science was developed against other forms of knowledge and, most militantly, against common-sense knowledge. This is as true of Galileo as of Durkheim. This separation between science and common sense came to be known in Bachelard's work as the epistemological rupture, subsequently applied to social science by Bourdieu. ${ }^{13}$ Indeed modern epistemology has developed as a controversy about the most adequate criteria, conditions, and procedures needed to draw the line between science and common sense. The insulation from common sense thus achieved enabled modern science to accumulate an impressive body of knowledge whose most legitimating promises were the domination of nature, the rationalization of life, and the emancipation of humankind.

However, after Hiroshima and Nagasaki, it became evident that mod-

9. Richard Rorty, Philosophy and the Mirror of Nature 390 (Princeton, N.J.: Princeton University Press, 1980).

10. Id. at 320 .

11. Theodor Adorno, Against Epistemology: A Metacritique (Cambridge, Mass.: M.I.T. Press, 1984).

12. See my works cited in note 5 . 1968).

13. Pierre Bourdieu \& J.-J. Chamboredon, Le Métier de Sociologue (Paris: Mouton, 
ern science was not fulfilling its promises and, if anything, it was distancing itself from such goals. In my view, the emancipating potential of modern science has been neutralized by the same process that created it, the epistemological rupture. As long as science is kept apart from common sense it cannot contribute toward the radical democratization of social life. The separation from current, mystifying common sense (the first, modern epistemological rupture) must be followed by the dissolution of scientific knowledge into a new, more democratic common sense (the second, postmodern epistemological rupture). Hence my notion of the double epistemological rupture. The mortal nature of postmodern science lies in its aspiration to dissolve itself in the social construction of a new common sense.

However, precisely because we are dealing with a social construction, the new common sense cannot be conceived of as the magical product of a theoretical condition (the double rupture). Postmodern scientific knowledge will be as much the product of theoretical conditions as of social conditions. The normative description of the latter constitutes a political agenda. Though this agenda must vary according to time and place, its most general premise is the idea of postmodern socialism conceived of as the globalization of participatory democracy. This premise involves, among other things, the substitution of the edifying application of science for the technical application of science. Contrary to technical application, edifying application eliminates the subject/object distinction, thereby demanding that the scientist (both the individual scientist and the local scientific communities) be personally and existentially involved in the social contexts in which scientific knowledge transforms common sense knowledge, thereby transforming itself. But since common-sense knowledge is not monolithic and is rather differentiated according to the social sites in which it is produced, the edifying application of science is premised upon a structural inquiry into the number and nature of such sites. I have argued elsewhere that the structural sites of the production of commonsense knowledge in capitalist societies are the household place, the workplace, the citizenplace, and the worldplace. ${ }^{14}$ What this means is that, among the myriad of configurations of knowledge in which postmodern science will dissolve, four are singled out as particularly crucial: domestic knowledge, production knowledge, national public sphere knowledge, and knowledge of the world. Scientists must be responsible for the edifying use of their specific knowledge in such a way as to promote and expand the participatory democratic content of any of the four configurations of common-sense knowledge. From the point of view of a postmodern science this is the context for a practice theory. In other words, practice theory is

14. Boaventura de Sousa Santos, "On Modes of Production of Law and Social Power," 13 Intem'l J. Soc. L 299 (1985). 
either its practice or a trivial contradiction: an immortal science cannot decide to be mortal.

\section{Toward a Mortal Sociology of Law}

I will now proceed to comment briefly on Coombe's and TrubekEsser's essays.

The two essays share a distaste for positivist social science and both advance specific proposals toward a mortal sociology of law, though Trubek-Esser's essay goes much further in this direction than Coombe's. Both relate their proposals to the research carried out in the Amherst Seminar on Legal Process and Legal Ideology, but while the Trubek-Esser's essay concentrates on this research, Coombe's refers to it as a mere illustration of an approach stated in general terms.

The critique of the positivist distinction (or rather, dichotomy) between structure and subjectivity constitutes the main focus of Coombe's attempt at reconstructing social theory and, more specifically, at mapping out new directions for a critical study of law. The argument is carried out with great consistency, even if in a somewhat repetitive way. Rejecting both the idea that structures "organize, explain or are reflected in subjective experiences" (Coombe at 72) and the idea "of a pure, unalienated subjectivity" (Coombe at 75), Coombe proposes a practice theory, which she takes from Bourdieu, conceived of as an approach that "explores the ways in which practices reproduce and change symbolic systems of power and domination and how these same systems construct the agents who realize and transform them" (Coombe at 121). The key concepts of the practice theory are the social field (hence, the juridical field) and the habitus.

Bordieu is without any doubt the leading European sociologist of our time, and his contributions extend far beyond the formulation of practice theory. His analyses of the educational system and of symbolic capital and social taste have become classic. ${ }^{15}$ However, it is a bit strange to see his theories converted into the solution for the impasses of American sociology and particularly of American sociology of law. Bourdieu has, of course, been influenced by the American sociological tradition, which provided him with the theoretical instruments to find a third way between (or above) Sartrian existentialism and Levy-Straussian structuralism. The idea of social field is already present in Michael Polanyi's Personal Knowledge, ${ }^{16}$ and the idea of habitus is indebted to American cultural anthropology.

15. Pierre Bourdieu \& J.-C. Passeron, La Reproduction (Paris: Minuit, 1970); Pierre Bourdieu, La Distinction (Paris: Minuit, 1979).

16. Michael Polanyi, Personal Knowledge (Chicago: University of Chicago Press, 1962). 
Not surprisingly, the concept of habitus overlaps with the concept of ideology as used in the Amherst literature (Trubek-Esser at 28). The influence of the American sociological tradition is even more apparent in Bourdieu's sociology of law, thus perhaps ironically accounting for Coombe's disappointment that "Unfortunately, Bourdieu's general sociology suggests more potential than his specific discussion of the juridical field realizes" (at 107).

The most salient feature of practice theory is that, as its name suggests, it takes seriously the way ordinary people think and act and tries to do justice to the complexities of human practice. However, it accomplishes that by claiming for sociology the status of a highly privileged, extraordinary knowledge. In the Bachelardian tradition, Bourdieu's sociology follows the principle of the first epistemological rupture or, in Trubek-Esser's terms, the principle of universal scientism. It is an immortal thinking about the ways mortal people think and act.

In his inaugural lecture at the Collège de France, in a formulation that echoes Durkheim, Bourdieu emphasizes that "the ambition to make a science of beliefs presupposes a belief in science . . . a belief in the liberating virtues of the least illegitimate symbolic power, the power of science, particularly when the latter takes the form of a science of symbolic powers which is capable of giving back to the social subjects the control of the false transcendencies that ignorance constantly creates and recreates."17 What is left unquestioned in this formulation is the idea that "by making a belief structure visible one can destroy its power over the subject concerned" (Coombe at 73). Bourdieu is above all concerned with producing an objective, rigorous knowledge, a form of knowledge as free from the interference of common sense knowledge as possible. He is least concerned with the consumption of that knowledge, with its impact on society, and with the conditions under which it can be appropriated by oppressed social groups.

In obedience to the principle of the universal scientism and indeed in order to confirm its validity beyond reasonable doubt, Bourdieu proposes to apply to the production of sociological knowledge the criteria, theories, and methods used by sociology to analyze society. For instance, sociological observation should, in his view, always be complemented by a sociology of sociological observation. More generally, the sociology of sociology should be part of the sociological method. This is the Bourdieuian version of "reflexive sociology," but here again it does not seem to add much to the rich tradition of reflexivity in American sociology, from Mills's Sociological Imagination of $1959,{ }^{18}$ to Howard Becker's address to the Society for

17. Pierre Bourdieu, Leçon sur la Leçon 56 (Paris: Minuit, 1982). 1970).

18. C. Wright Mills, The Sociological Imagination (London: Oxford University Press, 
the Study of Social Problems in 1966, "Whose Side Are We On?"19 or still to Alvin Gouldner's most eloquent and dramatic "reflexive sociology."20

Coombe resorts to Bourdieu to transcend the impasses of American sociology of law, but in light of the above, I tend to conclude that this démarche constitutes a "false transcendency." I fully agree with the theoretical objective underlying practice theory, that is, I too support the idea of conceiving the relations between "subjectivity" and "structure" in a way that would be commonsensical if such concepts existed at all in commonsensical reality. But the decisive issues of sociology in the last decades of the century will not concern the sophistication and complexity of our theories but rather the use we can make of them to generate a new common sense, be it a juridical, artistic, political, or religious common sense, a common sense capable of converting the utopia of participatory democracy into a reasonable political agenda. Such new common sense will transform the "illusion of transparence" (Durkheim) of the existing common sense into a commonsensical (and, therefore, not reserved to enlightened scientists) transparency of existing illusions, thereby opening the way to their supercession. Since the late 1960s (and not only since 1982, as the Amherst Seminarians are the first ones to recognize) critical sociology of law has accumulated an immense stock of knowledge that could be precious in the development of a new juridical common sense. Why has such development not occurred? This is the important question, rather than the question about subjectivity and structure.

Trubek and Esser go much further in addressing the decisive question than Coombe. It is true that they don't see the social construction of a new common sense as part of the political agenda, but they do see the need for a political agenda. The critical sociology of law they are aiming at is perhaps more modern than postmodern, but the nuance is, at this stage, probably irrelevant. Since to see the need for a political agenda is a political agenda itself, in the following I will comment on Trubek-Esser's essay in light of their political agenda.

\section{The Sociology and the Politics of the Sociology of the Amherst Seminar}

As I indicated at the beginning of the preceding section, TrubekEsser's essay advances more than Coombe's toward a mortal sociology of law. The reason lies in their critique of what they call "universal scien-

19. Howard Becker, "Whose Side Are We On?" in L. Reynolds \& J. Reynolds, eds., The Sociology of Sociology (New York: David McKay, 1970).

20. Alvin Gouldner, The Coming Crisis of Western Sociology (New York: Avon, 1971). 
tism" and in their explicit acknowledgement that knowledge is politics and that accordingly "one must consider the empirical impact which the knowledge one is constructing will have on specific persons, groups, and institutions, and decide whether one is ready to accept responsibility for this impact" (Trubek-Esser at 44). Indeed the only criticism they make of the Amherst Seminar concerns its failure to discard universal scientism and its silence or at least its ambiguity as to the impact of its work, that is, as to its political agenda: "No Amherst scholar has as yet produced a scholarly article that explicitly champions a specific marginalized group, consciously constructed a knowledge which can be used to advance their politics, and/or explicitly stated that the purpose of the work is to advance this group's political agenda" (at 45).

It is not my purpose to question either the factual description or the specific critical analysis of the Amherst Seminar scholars undertaken by Trubek and Esser but rather to speculate about the internal logic of their social construction of the Amherst Seminar and, applying Trubek-Esser's epistomological criteria to their own essay, to inquire into the impact of their essay on the Amherst Seminar and on American sociology of law as a way of trying to make explicit their political stance, in sum, their political agenda.

\section{The Social Construction of the Amherst Seminar}

For me, and probably for some other people, the "Amherst Seminar" has been up until now a group of fine colleagues that besides being excellent scholars are marvelous human beings whose company is relaxing and pleasant and with whom it is possible to entertain exciting debates not only about the nitty gritty of the sociology of law but also about the "conversation of humankind." I never counted them and never thought it important to know who belonged and who didn't belong to the group. I always found many "elective affinities" between their work and my own work, but never occurred to me that they (and myself?) could be a paradox or a program, yet alone a Pandora's box.

But Trubek-Esser's essay changed it all. All of a sudden, nothing that has been relevant for me up until now is relevant anymore. And inversely, things that I have neglected or simply ignored become extremely relevant, such as: The Amherst Seminar has "a project" (Trubek-Esser at 13); they have a name, "critical empiricism"; they have a definite number of members, meaning presumably either that they don't accept any new members or that they have formal rules to accept them; they meet regularly; they have invited a selected number of visiting scholars (apparently it is significant that they have invited me, indeed twice; in my modesty, I had always thought that it had been significant only for me); they have undertaken a 
systematic critique of the "instrumental" theory of action and of the liberal legalist view of law; they have "developed multiple research programs with potentially divergent implications" (at 46); they have sometimes failed to measure up to their own standards, and this explains the paradox that they have been both critical and empirical but have failed to really be both; and finally and most exciting they are a Pandora's box, though (not so excitingly) the surprises will only surprise those who cannot read the oracle of Law and Sociery Delphi.

Trubek-Esser's essay has disintegrated my common-sense image of the Amherst Seminar and reintegrated it into a more general, more rigorous, and more coherent image. This has made me reread some of the Amherst Seminar papers about themselves, only to come to conclusion that indeed their self-image seems to be closer to Trubek-Esser's image of them than to my original one. All of a sudden, and very much like a Gestalt transformation, the Trubek-Esser construction of the Amherst Seminar appears to be obvious ... almost commonsensical. However, bearing in mind TrubekEsser's admonitions, such transformation is neither so simple nor without consequences. Even if I fully agree with Trubek-Esser's view of our "own complicity in knowledge construction" (at 45) and subscribe to their suggested rejection of the idea "that science can and often does provide an authoritative description, or re-presentation, of the world" (at 45), I should not forget that one of these authors, David Trubek, is without any doubt a leading sociologist of law, who probably more than anyone else in the last two decades has contributed to create, among the sociologists of law, a sense that they belong to a distinct scientific community with an autonomous tradition. This means that the authority of Trubek's description of the Amherst Seminar is relatively independent of the authority of the science he resorts to to make such description. In view of this and because authority should be evaluated by the changes it accomplishes in reality, it seems legitimate to inquire about the impact of Trubek-Esser's essay on the American community of sociologists of law and on the Amherst Seminar itself.

If, in a Bourdieuian turn, I were allowed to use concepts developed by the sociology of law to analyze Trubek-Esser's analysis of the Amherst sociology of law, I would resurrect an old concept, Bohannan's double institutionalization, ${ }^{21}$ and suggest that through Trubek-Esser's essay the Amherst Seminar is being doubly institutionalized. The native order that has been emerging in the interstices of the participants' decision to get together, to meet regularly, to comment on each other's papers, to exchange views both on scientific and on professional and personal matters is now being doubled by the external order of Trubek-Esser's normative description of

21. Paul Bohannon, ed., Law and Warfare 45 (Garden City, N.Y.: Natural History Press, 1967). 
their work. Thereby the tacit organization of the group is made explicit. Though the informal character of the seminar is acknowledged (TrubekEsser at 13) the scientific (formal) description of its informality makes it appear more formal. Similarly, the coherent description of the incoherences of the group's work make the latter look more coherent. In sum, the Amherst Seminar is turning into an institution, and indeed they are said to have "institutional coherence" (id.). Thus, the contradictions, divergences, and multiplicities inside it take place at a higher level of institutional complicity and therefore are minimized by the very same analytical procedure that draws attention to them.

What will be the impact of this social construction upon the seminar itself? Will the participants recognize themselves in Trubek-Esser's normative description of their work? If they do, will they try to solve the contradictions, the ambiguities, the paradoxes that Trubek-Esser have identified in their work? To what extent will this change their scientific priorities? Which other contradictions, ambiguities, and paradoxes will grow uncontrolled only because they have not been identified by Trubek-Esser and are therefore authoritatively and safely declared nonexistent? If the seminar's participants don't recognize themselves in Trubek-Esser's normative description, what will their reaction be? Will they try to produce an official version of their work and objectives or will they go on doing the work they have been doing so far, hoping that they will thereby manage in time to impose their counterimage? Assuming that Trubek-Esser's central political strategy consists of forcing the seminar participants to make their political agenda explicit, will they agree on the need to do so? And if they don't agree on tactics or on objectives, will they see themselves forced from now on to solve the disputes ensuing therefrom? And in this case, will they apply to their own disputes the knowledge they have accumulated about disputing behavior and dispute settlement? Will they lump them or find informal alternative settlement mechanisms?

Be that as it may, it is evident that Trubek-Esser's essay will confer more respectability and visibility upon the Amherst Seminar. The latter's market value will accordingly change. Indeed they may change the market altogether, from a relatively marginal hidden economy of sociology of law on to the official, mainstream economy. As they become more respectable, they may decide to live up to the demands of respectability or, instead, use the "symbolic capital" thus acquired to force into mainstream acceptance ever more extreme marginal thought and radical political agendas. As they become more visible, they will be sought after, courted by people that would like to join them and participate in their project. Will they accept anyone or will they select the new adherents very carefully? On the basis of which criteria? Will such criteria allow me to join in; or Trubek 
and Esser, who indeed have already applied: "our project is largely the same as that we have been reviewing" (at 46)?

In spite of all these questions and possible dilemmas, I must confess that I am not much preoccupied about the ways the Seminar will respond to or solve them. Because, whatever their decision, I am sure they will go on being excellent scholars and beautiful human beings.

\section{The Great Tradition}

Far more serious, I would venture, will be the impact of TrubekEsser's essay on the American community of sociologists of law. The basic theoretical premise of this paper is that "the history of the formation of the law and society movement can be told as a cycle of disintegration and reintegration, or as rotation in mainstream legal culture" (at 8). There is, thus, a great tradition and, as any great tradition, it "has never been as monolithic as the critics sometimes suggest" (at 12). The conception of a great tradition encompasses both the idea of continuity and the idea of discontinuity, but it tends to decide the fate of any specific discontinuity in favor of an underlying continuity. This is precisely what occurs in the normative description of the Amherst Seminar. Though the novelty of the seminar's work, the "new project," is duly acknowledged and indeed such acknowledgment is the raison d'etre of Trubek-Esser's essay, in the end such novelty is not so novel after all, since the seminar's work "is both an expression of the best aspect of what the law and society movement has always stood for and its best hope of future vitality" (at 47). The newness of the Amherst project is thus dedramatized. The disintegration of the law and society tradition they have attempted has been reintegrated. Seen from a different angle, we could venture to say that the respectability and visibility conferred upon the Seminar participants exacts a price: the exalting marginality may dissolve into a boring centrality. If the new energies to overcome the current "autumnal period" (at 5) are to be found in the immortal summer of the law and society movement, could it be that we are seeking new energies against the autumn . . . in an Indian Summer?

Because they are not the embryo of a counter-tradition but rather a small (even if the best) part of the Tradition, self-criticism is not, as it seems, the opposite of self-congratulation (at 5). Self-criticism is self-congratulation under a different name.

\section{Self-Criticism as Self-Congratulation}

It should by now be clear that I end up agreeing with most of what Trubek and Esser have to say about the Amherst Seminar, and I suspect that the same is true of the Seminar participants themselves. The coinci- 
dence among all our social constructions creates an effect of facticity that we can safely take as being the reality. This being the case, we can start from here to express, exchange, and eventually share our worries and hopes about the critical sociology of law in the coming years. What follows is a chaotic enumeration, much in the vein of Borges' chinese classifications.

1. On being updated. I have often thought that sociolegal studies have an extreme difficulty in catching up with the most recent developments in both social theory and epistemology. What they try to incorporate as the newest is either not the newest anymore or a mere remake of old, forgotten thought. In the 1960s, the law and society movement adopted a predominantly positivist epistemology at a time in which positivism was already under attack (even in American sociology). The Critical Legal Studies movement consolidated itself as a critique of ideology at a time in which the latter was being replaced (or expanded) by other approaches, from the theory of structuration (Giddens) to the theory of practice (Bourdieu) or to the theory of communicative action (Habermas), and above all by Foucault's conception of knowledge-power. Today's "critical empiricism" emerges at a moment in which modern critical sociology is trying a new articulation with oppositional postmodern thought.

2. On epistemology. It is not enough to criticize "universal scientism." New alternatives must be put forward. In my view, and as I proposed in my epistemological excursus, the new thinking should center around the creation of a new common sense, in our case, the creation of a new juridical common sense. My reasons for this view are stated in detail elsewhere, by coincidence (?) in a paper originally given as a public lecture at Amherst. ${ }^{22}$

Taking the construction of a new common sense seriously means, among other things, that we should not too readily discard the scientific agenda crystallized in the distinction law in the books/law in action. No matter how ponderous our theoretical reservations against it, we should bear in mind that underlying it there is the separation between intention and results which, as Jon Elster has recently emphasized, is a basic organizing scheme of ordinary, commonsensical understanding of social reality. ${ }^{23}$ So to play books against action and action against books may be a good way of investing our symbolic capital-particularly in America where the discrepancy between the promises of the myth of America and reality has originated a social-psychological "anxiety of election" which poets, better than anyone else, have given voice to: "between the promise of election

22. Boaventura de Sousa Santos, "The Postmodern Transition: Law and Politics" (Amherst College, 1988).

23. Jon Elster, Ulysses and the Sirens (Cambridge: Cambridge University Press, 1984); id, Sour Grapes (Cambridge: Cambridge University Press, 1985). 
and its failure, the language of American poetry finds its voice."24

3. On analytical tools. It is easier to abandon the instrumental theory than the analytical instruments it has developed. The instrumentalization that underlies legal culture has contaminated the concepts and methods we use to criticize it and this is why law and society is to be seen "as a legally constructed domain of social knowledge" (at 12). From instrumental tools to "convivial tools" as Ivan Illich would call them, ${ }^{25}$ the task ahead consists of inventing analytical frameworks that cannot be easily appropriated (instrumentalized) by legal doctrine and legal culture. We must advance by trial and error. In a recent paper I myself have outlined a sociological conceptualization of law based on cartography, starting from the metaphor of laws as maps and then taking the metaphor literally. ${ }^{26}$

4. On a worldwide local political agenda. Legal law is the quintessential national view of social space and time. It is accordingly out of focus with both the local (infrastate, intranational) and the global (suprastate, international). About the local, in the past 25 years, the sociology and the anthropology of law have accumulated an impressive body of knowledge in which concepts like legal pluralism and dispute processing have become central. As to the global, we have been so far much less successful. We have not been able to address ourselves with equivalent systematicity and sophistication to such questions as the nuclear threat, the ecological catastrophe, the issues of disarmament and peace, the bankruptcy of microethics, and the need for a global ethics. In sum, we have not incorporated in our theory and analyses the fact that we live in an interstate world system.

Both our theoretical agendas and our political agendas have to be developed on a local and on a global scale as well as on a national scale. The recognition of the differences among the scales and of the need to articulate them is of utmost importance. From multinational fast food chains to the labor market, from regional wars to cognitive mapping, the trend is toward differentiating integration; that is, toward a form of global integration that uses local identities and specificities instead of destroying them altogether. The new intellectual climate rejects both monolithic massification and liberal and humanistic universalism. Echoing this climate Fredric Jameson wrote recently: "it seems to me that one of our basic political tasks lies precisely in the ceaseless effort to remind the American public of the radical difference of other national situations." 27

24. Maria Irene Santos, "Poetry in America: The Question of Gender," Genre $X X$ at 153,156 (1987).

25. Ivan Illich, Tools for Conviviality (New York: Harper \& Row, 1973).

26. Boaventura de Sousa Santos, "Law: A Map of Misreading. Toward a Post-modern Conception of Law," 14 J.L. $\mathscr{E}$ S Soc'y 279 (1987).

27. Fredric Jameson, "Third-World Literature in the Era of Multinational Capitalism," 15 Social Text 65, 77 (1986). 
In the same paper, Jameson presents, as a working hypothesis, a stimulating distinction between third world literature and first world literature in the era of multinational capitalism. According to him, first world literature, that is, the Western realist and modernist novel, portrays a "host of fragmented subjectivities . . . dying individual bodies without collective pasts or futures bereft of any possibility of grasping the social totality." 28 It is thus based on "a radical split between the private and the public, between the poetic and the political, between what we have come to think of as the domain of sexuality and unconscious and that of the public world of classes, of the economic, and of the secular political: in other words, Freud versus Marx."29 On the contrary, "third world texts, even those which are seemingly private and invested with a properly libidinal $\mathrm{dy}$ namic, necessarily project a political dimension in the form of national allegory: the story of the private individual destiny is always an allegory of the embattled situation of the public third world culture and society." 30

Without daring to judge the specific merit of such sweeping hypothesis, what it shows is that the interpretive turn in the social sciences is quite compatible with comparative work and that this should advance beyond the instrumentalist agenda into the domain of cultural premises, symbolic universes, cognitive maps. This would make it possible, for instance, to compare at a deeper level the analytical and political agendas of third world, second world, and first world sociologies of law. Can they be the same in countries where there is no tradition of legal reformism? In countries where legal reformism is undistinguishable from political reformism? In countries where legal reformism is always apolitical? To answer questions such as these we cannot simply learn and compare results; we must learn and compare the processes of learning and the premises of comparison.

5. On sociology as an Un-American activity. Why does so much complex and well-meaning knowledge about society turn into increasingly trivial and meaningless politics? This question is probably a general one but assumes a specific acuity in American society. When I mentioned above that the decisive task for the critical social sciences in the coming decades consists of developing new symbolic assets which, through their stronger democratic content, reduce interactive exploitation and expand social competence (the new common sense), I should add that, in my view, American society is the one in which such task is most decisive. Here, probably more than anywhere else, the gigantic body of knowledge accumulated by the social sciences has shown a total incapacity to change the existing mystifying common sense; so much so that most of what circulates

28. Id. at 85 .

29. Id. at 69 .

30. Id. 
as scientific knowledge seems to be nothing else but the scientific facade of common sense. Conversely, an increasingly powerful, mediatic common sense incorporates those fragments of scientific knowledge that suit it and reduces all the rest, which often includes the most generous ideals, either to carnival or to Un-American activity. In the United States, perhaps more than anywhere else, intellectuals (and scientific work in general) have been evaluated by their capacity to answer and not by their capacity to question. That's why the price of marginality seems to be so high. It will suffice to think of the most distinguished American dissident of our time, Noam Chomsky.

Considering that legal ideology and reformism are at the roots of the myth of America, one would think that the critical sociology of law is well positioned to start discussing what would be the general profile of a perestroika in American society, assuming such a political development might occur. Would it occur, its specific features would have nothing to do with those of the Soviet perestroika, but it would probably be no less sweeping. There are disquieting signals (the debt, the budget, and the trade deficit, the loss of productivity and creativity of American industry, the dangerous undermining of an already incomplete "welfare state," the degenerative crisis of the democratic political system, the exhaustion of natural resources, etc.) and the "best aspect of what the law and society movement has always stood for" (Trubek-Esser at 47) will fail its advocates if it fails to address with radical vitality the problems behind these signals.

With a glimpse of imagination one could speculate that there is an opportunity waiting to be seized by critical sociology of law. Indeed the type of socialism that Sombart considered incompatible with American society is undergoing a final crisis. From its ashes new types of socialism are emerging - oftentimes old types long forgotten in the vast attic of the socialist tradition-such as the associational, cooperative, mutualist socialism, all of them congenial to the Tocquevillian "best aspects" of American society.

6. On Saint-Simon's festivals. In one of his many projects for social and political reconstruction through industry and science, Saint-Simon imagined a parliament with two chambers. One of them was called the Chamber of Invention and was composed of engineers and intellectuals of all sorts, painters, writers, poets, sculptors, and musicians. According to the Constitution this chamber was to be in charge of organizing on a regular basis two types of festivals to be shown throughout the country: the festivals of remembrance, aimed at reminding the people of the miseries of the old social system; and the festivals of hope, aimed at showing the people the glorious promises of the new social system.

Saint-Simon's proposal marks the transition from the conception of the intellectual whose capacity to question is the most valued, symbolized 


\section{LAW AND SOCLAL INQUIRY}

by les philosophes, to the conception of the intellectual whose capacity to answer is the most valued, symbolized by the organic intellectuals of the welfare state. Many of us still see ourselves as members of a worldwide Chamber of Invention and, in the end, what distinguishes us is either the preference for questioning or the preference for answering. Both Coombe's essay and Trubek-Esser's essay can be seen as pieces for an upcoming festival of both remembrance and hope, in which the preference for questioning will dominate. I have dared to join them. Curtains up! 